\title{
Trends in HbA1c and other biochemical outcomes of individuals with newly diagnosed type 1 diabetes
}

\author{
A. O'Carroll-Lolait ${ }^{1} \cdot$ A. Urwin ${ }^{2} \cdot$ I. Doughty ${ }^{3} \cdot$ J. Schofield ${ }^{2} \cdot$ H Thabit $^{2,4} \cdot$ L. Leelarathna $^{2,4}$ (D)
}

Received: 5 September 2020 / Accepted: 11 November 2020 / Published online: 24 November 2020

(C) The Author(s) 2020

\begin{abstract}
Background There is limited data on glycaemic control and cardiovascular risk factor management in newly diagnosed individuals with type 1 diabetes in the first 2 years.

Methods Retrospective, single centre study from the North West of England, newly diagnosed with type 1 diabetes between 2014 and $2018(n=58)$. HbAlc, blood pressure, lipids and body mass index (BMI) data were collected from electronic patient records from the time of diagnosis until the end of 2 years, stratified by age 16-24 years or $\geq 25$ years at presentation.

Results For those aged 16-24 years $(n=31)$, median (IQR), HbAlc improved at 6 months from 83 (63-93) to 51.5 (46-75) $\mathrm{mmol} / \mathrm{mol}(p=0.001)$ and remained stable $6-24$ months. For those $\geq 25$ years $(n=27)$, HbAlc declined from 91 (70-107) to 65 $(50-89) \mathrm{mmol} / \mathrm{mol},(p<0.01)$ at 6 months and declined further to $52 \mathrm{mmol} / \mathrm{mol}(44-70)$ at $24 \mathrm{months}$. At $24 \mathrm{months}, 27.8 \%$ of all individuals had an $\mathrm{HbAlc} \geq 69 \mathrm{mmol} / \mathrm{mol}$. Approximately, a third met LDL $(<2 \mathrm{mmol} / \mathrm{L})$ and total cholesterol $(<4 \mathrm{mmol} / \mathrm{L})$ targets. A total of $58.6 \%$ of individuals were overweight/obese (BMI $>25 \mathrm{~kg} / \mathrm{m}^{2}$ ) at 24 months compared to $45.8 \%$ at baseline. There were no significant blood pressure changes during the follow-up.

Conclusions In both age groups, significant improvement of HbAlc occurred within the first 6 months of diagnosis with no statistical difference between the two groups at any of the time points up to 24 months. Despite significant improvements in $\mathrm{HbAlc}$, majority had levels $>53 \mathrm{mmol} / \mathrm{mol}$ at 24 months. Alongside the high incidence of obesity and dyslipidaemia, our data support the need for further intensification of therapy from diagnosis of type 1 diabetes.
\end{abstract}

Keywords Cardiovascular risk factors $\cdot$ Complications $\cdot \mathrm{HbA1 \textrm {c }} \cdot$ Type 1 diabetes

\section{Introduction}

Diabetes is one of the most common chronic medical conditions in Europe. Relative to the adult population, the incidence of new onset type 1 diabetes (T1DM) is higher in adolescents

\section{Leelarathna}

lalantha.leelarathna@mft.nhs.uk

1 School of Medicine, Faculty of Biology, Medicine and Health, University of Manchester, Manchester, UK

2 Manchester Diabetes Centre, Manchester University NHS Foundation Trust, Manchester Academic Health Science Centre, Manchester, UK

3 Royal Manchester Children's Hospital, Manchester University NHS foundation Trust, Manchester, UK

4 Division of Diabetes, Endocrinology and Gastroenterology, Faculty of Biology, Medicine and Health, University of Manchester, Manchester, UK but the prevalence is increasing in all age groups.[1]. The classic symptoms of polydipsia, polyuria, tiredness and weight loss, along with overt hyperglycaemia, are more commonly seen in children, with the presentation in adults often more variable.[2] Great effort is required from both patients and carers to lower $\mathrm{HbA} 1 \mathrm{c}$ levels to the recommended targets, due to the need to maintain lifelong insulin administration, regular blood glucose self-monitoring and stringent lifestyle management to achieve optimal glycaemic control. Healthcare providers use $\mathrm{HbAlc}$ measurements to monitor patients' long-term glycaemic control, but target HbA1c levels differ between countries and ages. The National Institute for Health and Care Excellence (NICE) in the UK recommends a target $\mathrm{HbAlc}$ of $<48 \mathrm{mmol} / \mathrm{mol}$ for both children and adults to minimise the risk of developing complications.[3] Whereas in the USA, the American Diabetes Association (ADA) recommends a target $<58$ $\mathrm{mmol} / \mathrm{mol}$ for children and $<53 \mathrm{mmol} / \mathrm{mol}$ for adults. [4] Individuals with diabetes are at higher risk of cardiovascular 
disease (CVD). This risk can be estimated through assessing multiple biochemical factors. NICE no longer specify exact targets for lipid measurements for people with T1DM, however to reduce the risk of CVD, targets of $<4 \mathrm{mmol} / \mathrm{L}$ for total cholesterol (TC),$<2 \mathrm{mmol} / \mathrm{L}$ for $\mathrm{LDL}, \leq 1.7 \mathrm{mmol} / \mathrm{L}$ for triglycerides and either $\geq 1.0 \mathrm{mmol} / \mathrm{L}$ (men) or $\geq 1.3$ $\mathrm{mmol} / \mathrm{L}$ (women) for HDL, have been identified by Diabetes UK as a guide for people with T1DM.[5] The combination of poor glycaemic control with dyslipidaemia and obesity predisposes individuals with T1DM to develop micro- and macrovascular complications.

Evaluating the actual physical, social and economic burdens of T1DM is challenging. [1]. However, it has been well documented that achieving optimal glycaemic control is important to reduce the incidence of developing complications associated with significant morbidity and mortality.[6] Complications can be categorised into microvascular (retinopathy, nephropathy or neuropathy) or macrovascular (CVD, cerebrovascular disease and peripheral vascular disease).[7] Results from the Diabetes Control and Complications Trial (DCCT) and its long-term follow-up, the Epidemiology of Diabetes Interventions and Complications (EDIC) study have clearly demonstrated that hyperglycaemia has a causal role in the development and progression of both microvascular and macrovascular complications. [8, 9] CVD is more prevalent amongst those with T1DM than the nondiabetic population, with a 10-fold increase of CVD seen in those with T1DM than without.[10] There are multiple identifiable risk factors associated with CVD, such as HbA1c, blood pressure (BP), obesity and lipids, that can be monitored and managed in those with T1DM to reduce this risk.[6] The purpose of this study was to look at progression of $\mathrm{HbA} 1 \mathrm{c}$ levels, and cardiovascular risk factors during the first 2 years of T1DM diagnosis.

\section{Materials and methods}

This was a retrospective, observational, single-centre, service evaluation from the North West of England. Results were included for those diagnosed with T1DM between 2014 and 2018, and who have a minimum of 12 months of subsequent electronic clinic records data.

As this was a service evaluation, no ethical approval was required. $\mathrm{HbA} 1 \mathrm{c}$ values were obtained at 6 monthly intervals from presentation throughout the first 2 years. Data on BP, lipids, and body mass index (BMI) were collected at presentation, and 12 and 24 months post-diagnosis, as these are the time points at which patients undergo more extensive evaluation.

Glycaemic control was assessed using targets outlined by NICE. [3] HbAlc levels of $\leq 48(\leq 6.5 \%), \leq 58(\leq 7.5 \%)$ and $\geq$ $69(\geq 8.5 \%) \mathrm{mmol} / \mathrm{mol}$ were used as targets to assess glycaemic control amongst our cohort. BP control was assessed using NICE-recommended targets of systolic BP $<$
$135 \mathrm{mmHg}$ and diastolic $\mathrm{BP}<85 \mathrm{mmHg}$.[3] BP measurements were typically recorded using a single sitting reading. If the measurement was raised, a second sitting reading after 5 min was performed and the lower of the two values was used. BMI measurements were categorised as underweight $\left(<18 \mathrm{~kg} / \mathrm{m}^{2}\right)$, normal $\left(18-25 \mathrm{~kg} / \mathrm{m}^{2}\right)$, overweight $(25-30 \mathrm{~kg} /$ $\left.\mathrm{m}^{2}\right)$ and obese $\left(>30 \mathrm{~kg} / \mathrm{m}^{2}\right)$. Target lipid levels were defined as $\mathrm{TC}<4 \mathrm{mmol} / \mathrm{L}, \mathrm{LDL}<2.0 \mathrm{mmol} / \mathrm{L}, \mathrm{HDL}>1.0 \mathrm{mmol} / \mathrm{L}$ (men) or $>1.3 \mathrm{mmol} / \mathrm{L}$ (women) and triglycerides $<1.7$ $\mathrm{mmol} / \mathrm{L}$. A less aggressive LDL target of $<2.6 \mathrm{mmol} / \mathrm{l}$, consistent with ADA, ISPAD and ESC/EASD recommendations $[2,11]$ was used for secondary analysis.

The cohort was stratified by age at presentation into those aged $16-24$ years and those aged $\geq 25$ years at diagnosis. This allowed comparisons to be made and analysed between the two groups.

We used the IBM SPSS version 25 for statistical analysis. Data were mostly non-normally distributed so we have shown median (IQR) and used non-parametric tests for comparison of two groups.

\section{Results}

Between January 2014 and April 2018, 58 patients between the ages of 16 and 54 years were diagnosed with T1DM at Manchester Royal Infirmary. Participants were divided into young adult (16-24 years old, $n=31$ ) and adult (25 years and above, $n=27$ ) age groups. Baseline characteristics for the whole cohort are shown in Table 1.

Table 1 Baseline characteristics

\begin{tabular}{lll}
\hline Characteristic & Data & $N(\%)$ \\
\hline$N$ & 58 & \\
Females & $34(59 \%)$ & \\
Age at diagnosis (year) & $24(20,32)$ & \\
Aged 16-24 years* & $31(53 \%)$ & $31(53)$ \\
HbAlc $(\mathrm{mmol} / \mathrm{mol})$ & $86(66,95)$ & $53(91)$ \\
TCa $(\mathrm{mmol} / \mathrm{L})$ & $4.20(3.75,4.90)$ & $53(91)$ \\
HDL-Cb $(\mathrm{mmol} / \mathrm{L})$ & $1.57(1.27,1.83)$ & $50(86)$ \\
LDL-C $^{c}(\mathrm{mmol} / \mathrm{L})$ & $2.21(1.62,2.78)$ & $53(91)$ \\
Triglycerides $(\mathrm{mmol} / \mathrm{L})_{\mathrm{BMI}^{\mathrm{d}}\left(\mathrm{kg} / \mathrm{m}^{2}\right)}^{1.00(0.70,1.50)}$ & $35(60)$ \\
\hline
\end{tabular}

Data are $N(\%)$ or median (IQR) unless stated

$N(\%)$, number of patients with data (percentage of total cohort)

${ }^{\text {a }} T C$, total cholesterol

${ }^{\mathrm{b}} H D L-C$, high-density lipoprotein cholesterol

${ }^{\mathrm{c}} L D L-C$, low-density lipoprotein cholesterol

${ }^{\mathrm{d}} B M I$, body mass index

*No. of patients aged 16-24 at time of diagnosis 


\section{Glycaemic control (Table 2)}

$\mathrm{HbA1c}$ measurement availability at diagnosis, 6, 12, 18 and 24 months was $53 \%, 79 \%, 77 \%, 63 \%$ and $62 \%$. Table 2 shows median $\mathrm{HbAlc}$ levels for the whole cohort and stratified by age group at 6 monthly intervals from diagnosis to 2 years post-diagnosis, and the proportion (\%) of patients reaching $\mathrm{HbAlc} \leq 48$ and $\leq 58 \mathrm{mmol} / \mathrm{mol}$.

For the whole cohort, we noted significant improvement in HbA1c between diagnosis and 24 months, $86(66,95)$ to 52 $(46,70) \mathrm{mmol} / \mathrm{mol}, p=0.001$. This improvement predominantly occurred between the diagnosis and 6 months, 86 (66, $95)$ to $58.8(48,76) \mathrm{mmol} / \mathrm{mol}, p<0.001$. Median HbAlc at diagnosis was higher in the older cohort than the younger (91 vs $83 \mathrm{mmol} / \mathrm{mol}$ ) but did not reach statistical significance ( $p=$ 0.143 ). (Table 2) Similarly, the older group had higher median HbA1c levels during the initial 12 months of the study period compared to the younger group, without statistical significance. At 24 months, both groups recorded similar median $\mathrm{HbA1c}$ results.

In the younger cohort, the proportion of patients achieving a $\mathrm{HbA} 1 \mathrm{c} \leq 48 \mathrm{mmol} / \mathrm{mol}$ decreased from 6 to 24 months post-diagnosis ( 36.4 to $23.5 \%$ ) but the proportion achieving a $\mathrm{HbA} 1 \mathrm{c} \leq 58 \mathrm{mmol} / \mathrm{mol}$ increased (59.1 to $70.6 \%$ ), whilst in the older cohort, the proportion of patients achieving both of these targets rose with $36.8 \%$ achieving a $\mathrm{HbAl} 1 \mathrm{c} \leq 48 \mathrm{mmol} / \mathrm{mol}$ at 24 months (a rise from $16.7 \%$ at 6 months) and $63.2 \%$ achieving a $\mathrm{HbA} 1 \mathrm{c} \leq$ $58 \mathrm{mmol} / \mathrm{mol}$ (a rise from $41.7 \%$ at 6 months). At 24 months, $27.8 \%$ of all individuals had a $\mathrm{HbAlc} \geq 69$ $\mathrm{mmol} / \mathrm{mol}$, with $29.4 \%$ of those aged $16-24$ and $26.3 \%$ of those $\geq 25$ within this range.

\section{Cardiovascular risk factor levels}

Data availability at 24 months for SBP, DBP, TC, LDL, HDL, triglycerides and BMI were 76\%, 76\%, 78\%, 74\%, 78\%, 78\% and $84 \%$, respectively. In the older group, hypercholesterolaemia (TC $>4 \mathrm{mmol} / \mathrm{L}$ ) was found in $62.5 \% 24$ months postdiagnosis, with $47.8 \%$ having an LDL cholesterol $>2 \mathrm{mmol} / \mathrm{L}$ and $30.4 \%$ failing to reach the recommended LDL target of $<$ $2.6 \mathrm{mmol} / \mathrm{L}$. $[2,11]$ All of those aged $\geq 25$ years achieved satisfactory HDL cholesterol levels $(>1.0 \mathrm{mmol} / \mathrm{L}$ for men and $>1.3 \mathrm{mmol} / \mathrm{L}$ for women) but hypertriglyceridaemia (< $1.7 \mathrm{mmol} / \mathrm{L}$ ) was observed in $25 \%$ at 24 months postdiagnosis.

A significant percentage, $50 \%$ (9 out of 18), of the older cohort were overweight (BMI $>25$ ) or obese (BMI $>30 \mathrm{~kg}$ / $\mathrm{m} 2$ ) at time of diagnosis, which increased to $63.7 \%$ (14 out of 22 ) at 24 months post-diagnosis. Only $31.8 \%$ (7 out of 22 ) had a BMI within the ideal range (18 to $\left.25 \mathrm{~kg} / \mathrm{m}^{2}\right) 24$ months after diagnosis. BP levels were within range throughout the study period, with recommended systolic and diastolic targets met by the majority ( $81.8 \%$ for both) by study end.

The 16-24 age group showed similar results at 24 months, with hypercholesterolaemia found in $76.2 \%$ of individuals ( $45 \%$ had LDL $>2.6 \mathrm{mmol} / \mathrm{L}$ ) whilst high proportions achieved HDL and BP targets (95.2, 81.8 (systolic) and $100 \%$ (diastolic), respectively). Furthermore, overweight and obesity were common with $52.6 \%$ (10 out of 19 ) having a

Table 2 Glycaemic control covering the first 2 years of diagnosis

\begin{tabular}{|c|c|c|c|c|c|}
\hline & Diagnosis & 6 months & 12 months & 18 months & 24 months \\
\hline \multicolumn{6}{|l|}{ Whole cohort } \\
\hline $\mathrm{HbAlc}(\mathrm{mmol} / \mathrm{mol})$ & $86(66,95)$ & $58.8(48,76)$ & $52.5(45,66)$ & $55(48,70)$ & $52(46,70)$ \\
\hline$N(\%)$ & $31(53)$ & $46(80)$ & $45(78)$ & $37(64)$ & $36(62)$ \\
\hline \multicolumn{6}{|l|}{$16-24$ years } \\
\hline $\mathrm{HbAlc}(\mathrm{mmol} / \mathrm{mol})$ & $83(63,93)$ & $51.5(46,75)$ & $51(45,64)$ & $59(48,63)$ & $53(49,70)$ \\
\hline$\leq 48(\%)$ & 0 & 36.4 & 34.8 & 23.5 & 23.5 \\
\hline$\leq 58(\%)$ & 12.5 & 59.1 & 65.2 & 47.1 & 70.6 \\
\hline$\geq 69(\%)$ & 68.8 & 19.3 & 6.5 & 17.6 & 29.4 \\
\hline \multicolumn{6}{|l|}{$\geq 25$ years } \\
\hline $\mathrm{HbA} 1 \mathrm{c}(\mathrm{mmol} / \mathrm{mol})$ & $91(70,107)$ & $65(50,89)$ & $53.5(44,72)$ & $54(47,72)$ & $52(44,70)$ \\
\hline$\leq 48(\%)$ & 0 & 16.7 & 36.4 & 35.0 & 36.8 \\
\hline$\leq 58(\%)$ & 0 & 41.7 & 59.1 & 55.0 & 63.2 \\
\hline$\geq 69(\%)$ & 80.0 & 41.7 & 31.8 & 35.0 & 26.3 \\
\hline$p$ value & 0.143 & 0.099 & 0.307 & 0.647 & 0.612 \\
\hline
\end{tabular}

Data are median (IQR) and \% unless stated

$N(\%)$, number of patients with data (percentage of total cohort)

$p$ value is the comparison between the two cohorts at each time point (Mann-Whitney $U$ test) 
BMI $>25 \mathrm{~kg} / \mathrm{m}^{2}$ at 24 months, an increase from $41.2 \%$ (7 out of 17) at diagnosis, with less than half achieving a BMI within the ideal range.

\section{Participation in structured education (DAFNE course)}

Of the total cohort, 11 (19\%) individuals had undertaken the Dose Adjustment for Normal Eating (DAFNE) course. $\mathrm{HbA} 1 \mathrm{c}$ at 24 months in those who participated in the DAFNE course was not significantly different to those who did not do the DAFNE course. Amongst DAFNE attenders, the pre-course mean $\mathrm{HbA} 1 \mathrm{c}$ was $58.8 \mathrm{mmol} / \mathrm{mol}$ whilst postcourse mean $\mathrm{HbAlc}$ was $59.0 \mathrm{mmol} / \mathrm{mol}$ (no statistically significant difference).

\section{Discussion}

\section{Main findings}

In this study, we describe the changes in $\mathrm{HbAlc}$ and other cardiovascular risk factors in a cohort of patients with newly diagnosed type 1 diabetes presenting between 2014 and 2018 at a single centre followed up for 24 months. We observed significant improvements in the HbAlc within 6 months of the diagnosis which remained largely stable in the 6- to 24-month period. The percentage of people with HbA1c $\leq 58 \mathrm{mmol} / \mathrm{mol}$ was highest at 24 months for both age groups, but the percentage of people with $\mathrm{HbAlc} \leq 48 \mathrm{mmol} / \mathrm{mol}$ was highest in 16-24 cohorts at 6 months. A relatively large proportion of both cohorts still recorded HbAlc levels above 69 $\mathrm{mmol} / \mathrm{mol}, 24$ months after diagnosis, which is concerning given the well-known relationship between hyperglycaemia and development of long-term complications. [8, 9] Also of concern is the increasing prevalence of overweight and obesity within the cohort covered in this study, due to the adverse CVD risk outcomes associated with elevated BMI. Over half of the included population had a BMI $>25 \mathrm{~kg} / \mathrm{m}^{2} 24$ months after diagnosis.

\section{Comparison with published data}

Our BMI data are comparable with findings from the Health Survey for England conducted in 2018 in which $63 \%$ of all adults ( $>16)$ were overweight or obese. [12] One-third of the entire cohort in this study had hypercholesterolaemia (TC $>5 \mathrm{mmol} / \mathrm{L}$ ) 24 months post-diagnosis, fewer than the $47 \%$ of adults reported to have hypercholesterolaemia in the health survey. [12]. This remains a cause for concern given the strong association between age at onset of type 1 diabetes and excess cardiovascular disease [13] and evidence that lipid-lowering therapy is associated with a significant cardiovascular disease risk reduction amongst individuals with type 1 diabetes [14]. Adoption of the ADA and ISPAD LDL target of $<2.6$ $\mathrm{mmol} / \mathrm{L}$ for people with type 1 diabetes would identify $37.2 \%$ of this cohort as being 'above target'.[15] Attainment of target blood pressure measurements remained high within both cohorts throughout the study period.

The UK National Diabetes Audit 2019-2020 $(n=$ $245,565)$ reported that $31.8 \%$ of patients with type 1 diabetes of all ages achieved a $\mathrm{HbAlc} \leq 58 \mathrm{mmol} / \mathrm{mol}$ and $10.6 \%$ met the target of $\leq 48 \mathrm{mmol} / \mathrm{mol}$ [16]. Although not directly comparable due to different duration of diabetes in these two cohorts, in our cohort, $70.6 \%$ of those $16-24$ and $63.2 \%$ of those $\geq 25$ years achieved a HbAlc $\leq$ $58 \mathrm{mmol} / \mathrm{mol}$, and 23.5 and $36.8 \%$ (16-24 and $\geq 25$, respectively) meet the $\leq 48 \mathrm{mmol} / \mathrm{mol}$ target.[16] The national audit also reported $73.1 \%$ of patients meeting the BP target of $140 / 80 \mathrm{mmHg}$, with a higher proportion of patients in this study (93\%) achieving the same target.

Although large observational data sets are available, none have focussed solely on newly diagnosed patients. Internationally, the Swedish National Diabetes Register (NDR) publishes reports on national adult diabetes care.[17, 18] Their study reported a mean $\mathrm{HbA} 1 \mathrm{c}$ of $62.8 \mathrm{mmol} / \mathrm{mol}$ for patients with T1DM seen in specialist clinics in $2015(n=$ $33,287)$. They demonstrated that increasing proportions of patients were achieving treatment targets for $\mathrm{HbAlc}$ over the study period. Other biochemical parameters associated with the development of complications were also evaluated. Mean BP decreased throughout the study, and the proportion meeting the $140 / 85 \mathrm{mmHg}$ target stood at $78.6 \%$ at the end of 4 years. This study did not identify the results for newly diagnosed patients, so a direct comparison with our results could not be made.

Furthermore, the USA Type 1 Exchange Registry evaluated the HbA1c data of patients between 2016 and $2018(n=$ 22,697).[19] The ADA HbA1c goals for children $(<58$ $\mathrm{mmol} / \mathrm{mol})$ and adults $(<53 \mathrm{mmol} / \mathrm{mol})$ were being met by $17 \%$ and $21 \%$ of patients, respectively, considerably lower than the proportions meeting $\mathrm{HbAlc}$ targets in our study; however, the US study also did not identify newly diagnosed patients, so a direct comparison of results cannot be made.

Any differences in $\mathrm{HbAlc}$ values in relation to enrolment on a DAFNE course were also analysed. Our results highlight no statistical difference in the $\mathrm{HbAlc}$ values pre- and postenrolment on the course. This result is not surprising, as all participants were at early stages of their diagnosis.

\section{Strengths and limitations}

To our knowledge, this is the first study in the UK to report the evolution in $\mathrm{HbAl} 1 \mathrm{c}$ and cardiovascular risk factors in the first 2 years of diagnosis for both young adult and adult 
populations. Heald et al. published a study focusing on the intervention of diabetes specialist nurse services and the subsequent effects on HbA1c levels over an 18-month follow-up period from diagnosis. [20] The authors reported similar findings with significant initial reductions in $\mathrm{HbAlc}$, falling from $99 \mathrm{mmol} / \mathrm{mol}$ at diagnosis to $49 \mathrm{mmol} / \mathrm{mol}$ at 6 months $(p<$ 0.001 ), followed by no further improvement during the study period. Higher percentages of patients achieved $\mathrm{HbAlc}$ treatment targets at the end of the study, $84.6 \%$ achieved a $\mathrm{HbAlc}$ $<58 \mathrm{mmol} / \mathrm{mol}$ and $61.5 \%$ met a target of $<48 \mathrm{mmol} / \mathrm{mol}$. However, the study was limited by its small sample size $(n=$ 15 ) and population (only included adults). Our study is larger $(n=58)$ and includes a wider age range of participants, providing a better estimate of the evolution of glucose control in those initial years. A key limitation is the retrospective nature of this study, including the lack of information on each parameter for all individuals at each time point. For example, only $62 \%$ had $\mathrm{HbA} 1 \mathrm{c}$ data at 24 months. Therefore, it is possible that the percentage of individuals with $\mathrm{HbA1c}>69$ $\mathrm{mmol} / \mathrm{mol}$ could be higher than $27.8 \%$, as the $\mathrm{HbAlc}$ in those who have not attended clinic appointments could be higher. Although it is standard practice in our centre to perform autoantibodies measurements at diagnosis for anti-GAD and Islet cell antibodies, for the purpose of this analysis information on autoantibodies measurements were not collected. We therefore acknowledge that a minority in our cohort may have other types of diabetes.

In summary, our data show good improvements in HbA1c since diagnosis of type 1 diabetes in a cohort of adults and adolescents. Despite the initial improvements, more than a quarter of the population had very poor glucose control $(\mathrm{HbAlc} \geq 69 \mathrm{mmol} / \mathrm{mol})$ at 2 years. It will be very important to identify these individuals as soon as possible and institute additional measures to improve glycaemia in this group. In addition, a significant proportion of the cohort was overweight or obese at diagnosis with further weight gain during the first 2 years after diagnosis and associated high cholesterol levels. The 2019 ESC/EASD Guidelines have adopted new language around risk, with younger patients with short duration of diabetes and no other recognised risk factors still considered to be at moderate risk [21]. Our data calls for more aggressive management of glycaemic targets and cardiovascular risk factors in newly diagnosed patients with type 1 diabetes thereby reducing the risk of developing long-term micro- and macrovascular complications.

Author contributions All authors contributed to the study conception and design. Material preparation, data collection and analysis were performed by Aoife O'Carroll-Lolait and Lalantha Leelarathna. The first draft of the manuscript was written by Aoife O'Carroll-Lolait and all authors commented on previous versions of the manuscript. All authors read and approved the final manuscript.

Data availability Data was retrieved from electronic patient records.

\section{Compliance with ethical standards}

Conflict of interest The authors declare that they have no conflict of interest.

Ethics approval For this retrospective study using routinely collected data, ethical approval is not requested.

Informed consent For this type of study formal consent is not required.

Consent to participate/publication Identifiable patient details were anonymized, and service evaluation requiring no consent procedure.

Code availability Not applicable

Abbreviations BMI, body mass index; HDL, high-density lipoprotein; LDL, low-density lipoprotein; TC, total cholesterol; BP, blood pressure; T1DM, type 1 diabetes mellitus; HbA1c, haemoglobin A1c

Open Access This article is licensed under a Creative Commons Attribution 4.0 International License, which permits use, sharing, adaptation, distribution and reproduction in any medium or format, as long as you give appropriate credit to the original author(s) and the source, provide a link to the Creative Commons licence, and indicate if changes were made. The images or other third party material in this article are included in the article's Creative Commons licence, unless indicated otherwise in a credit line to the material. If material is not included in the article's Creative Commons licence and your intended use is not permitted by statutory regulation or exceeds the permitted use, you will need to obtain permission directly from the copyright holder. To view a copy of this licence, visit http://creativecommons.org/licenses/by/4.0/.

\section{References}

1. Atkinson MA, Eisenbarth GS, Michels AW (2014) Type 1 diabetes. Lancet 383:69-82. https://doi.org/10.1016/S0140-6736(13) 60591-7

2. American Diabetes Association. (2017) Medical management of type 1 diabetes. 7th ed. Wang CC, Shah AC, Eds. Alexandria, VA, American Diabetes Association 40 (Suppl. 1): S11-S24.

3. National Institute for Health and Care Excellence (NICE). (2015) Type 1 diabetes in adults: diagnosis and management. NICE guideline (NG17) published: 26 August 2015. https://www.nice.org.uk/ guidance/ng17/ resources/type-1-diabetes-in-adults-diagnosis-andmanage- ment-1837276469701.

4. American Diabetes Association (2018) 6. Glycemic targets: standards of medical care in diabetes-2018. Diabetes Care 41(Suppl. 1): S55-S64

5. Diabetes UK. Diabetes Health Guidelines (2019). Retrieved from https://www.diabetes.co.uk/diabetes-health-guidelines.html. Accessed 04/05/20

6. Swasey KK, Orchard TJ, Costacou T (2018) Trends in cardiovascular risk factor management in type 1 diabetes by sex. J Diabetes Complicat 32(4):411-417. https://doi.org/10.1016/j.jdiacomp. 2018.01.003

7. Melendez-Ramirez LY, Richards RJ, Cefalu WT (2010) Complications of type 1 diabetes. Endocrinol Metab Clin N Am 39(3):625-640. https://doi.org/10.1016/j.ecl.2010.05.009

8. The Diabetes Control and Complications Trial/Epidemiology of Diabetes Interventions and Complications (DCCT/EDIC) Study Research Group (2005) Intensive diabetes treatment and 
cardiovascular disease in patients with type 1 diabetes. $\mathrm{N}$ Engl $\mathrm{J}$ Med 353:2643-2653

9. Diabetes Control and Complications Trial Research Group (1993) The effect of long-term intensified insulin treatment on the development of microvascular complications of diabetes mellitus. $\mathrm{N}$ Engl J Med 329:304-309

10. Miller RG, Mahajan HD, Costacou T, Sekikawa A, Anderson SJ, Orchard TJ (2016) A contemporary estimate of total mortality and cardiovascular disease risk in young adults with type 1 diabetes: the Pittsburgh Epidemiology of Diabetes Complications Study. Diabetes Care 39:2296-2303. https://doi.org/10.2337/dc16-1162

11. Donaghue KC, Marcovecchio ML, Wadwa RP et al (2018) ISPAD Clinical Practice Consensus Guidelines 2018: microvascular and macrovascular complications in children and adolescents. Pediatr Diabetes 19(Suppl 27):262-274. https://doi.org/10.1111/pedi. 12742

12. Fuller E, Mindell J, Prior G The health survey for England 2018. NHS Digital, London http://digital.nhs.uk/pubs/hse2018. Accessed 12/07/2020

13. Rawshani A, Sattar N, Franzén S, Rawshani A, Hattersley AT, Svensson AM, Eliasson B, Gudbjörnsdottir S (2018) Excess mortality and cardiovascular disease in young adults with type 1 diabetes in relation to age at onset: a nationwide, register-based cohort study. Lancet 392(10146):477-486. https://doi.org/10.1016/ S0140-6736(18)31506-X

14. Hero C, Rawshani A, Svensson AM, Franzén S, Eliasson B, EegOlofsson K, Gudbjörnsdottir S (2016) Association between use of lipid-lowering therapy and cardiovascular diseases and death in individuals with type 1 diabetes. Diabetes Care 39(6):996-1003. https://doi.org/10.2337/dc15-2450

15. American Diabetes Association (2004) Dyslipidaemia management in adults with diabetes. Diabetes Care 27(Suppl. 1):s68-s71

16. National Diabetes Audit (NDA) (2019-2020) : Care processes and treatment targets (2020). https://digital.nhs.uk/data-and-information/publications/statistical/national-diabetes-audit. Accessed: 06/ 05/2020

17. Svensson A-M, Gudbjornstdottir S, Samuelsson P et al. (2016) The Swedish National Diabetes Register (NDR) 20 years report. Available from www.ndr.nu. Accessed 04/05/2020.

18. Gudbjornstdottir S, Cederholm J, Nilsson PM et al (2003) The National Diabetes Register in Sweden: an implementation of the St. Vincent Declaration for Quality Improvement in Diabetes Care. Diabetes Care 26(4):1270-1276. https://doi.org/10.2337/diacare. 26.4.1270

19. Foster NC, Beck RW, Miller KM, Clements MA, Rickels MR, DiMeglio LA, Maahs DM, Tamborlane WV, Bergenstal R, Smith E, Olson BA, Garg SK, for the T1D Exchange Clinic Network (2019) State of type 1 diabetes management and outcomes from the T1D exchange in 2016-2018. Diabetes Technol Ther 21(2):6672. https://doi.org/10.1089/dia.2018.0384

20. Heald AH, Anderson SG, Khan A, Stocker J, Davies S, Bliss K, Livingston M, Donnelly P (2017) Success rates in a diabetes specialist nurse-led education programme : re-setting the glucostat. Exp Clin Endocrinol Diabetes 125:297-300. https://doi.org/10. 1055/s-0042-108055

21. Cosentino F, Grant PJ, Aboyans V, Bailey CJ, Ceriello A, Delgado V, Federici M, Filippatos G, Grobbee DE, Hansen TB, Huikuri HV, Johansson I, Jüni P, Lettino M, Marx N, Mellbin LG, Östgren CJ, Rocca B, Roffi M, Sattar N, Seferović PM, Sousa-Uva M, Valensi P, Wheeler DC, ESC Scientific Document Group, Piepoli MF, Birkeland KI, Adamopoulos S, Ajjan R, Avogaro A, Baigent C, Brodmann M, Bueno H, Ceconi C, Chioncel O, Coats A, Collet JP, Collins P, Cosyns B, di Mario C, Fisher M, Fitzsimons D, Halvorsen S, Hansen D, Hoes A, Holt RIG, Home P, Katus HA, Khunti K, Komajda M, Lambrinou E, Landmesser U, Lewis BS, Linde C, Lorusso R, Mach F, Mueller C, Neumann FJ, Persson F, Petersen SE, Petronio AS, Richter DJ, Rosano GMC, Rossing P, Rydén L, Shlyakhto E, Simpson IA, Touyz RM, Wijns W, Wilhelm M, Williams B, Aboyans V, Bailey CJ, Ceriello A, Delgado V, Federici M, Filippatos G, Grobbee DE, Hansen TB, Huikuri HV, Johansson I, Jüni P, Lettino M, Marx N, Mellbin LG, Östgren CJ, Rocca B, Roffi M, Sattar N, Seferović PM, Sousa-Uva M, Valensi P, Wheeler DC, Windecker S, Aboyans V, Baigent C, Collet JP, Dean V, Delgado V, Fitzsimons D, Gale CP, Grobbee DE, Halvorsen S, Hindricks G, Iung B, Jüni P, Katus HA, Landmesser U, Leclercq C, Lettino M, Lewis BS, Merkely B, Mueller C, Petersen SE, Petronio AS, Richter DJ, Roffi M, Shlyakhto E, Simpson IA, Sousa-Uva M, Touyz RM, Zelveian PH, Scherr D, Jahangirov T, Lazareva I, Shivalkar B, Naser N, Gruev I, Milicic D, Petrou PM, Linhart A, Hildebrandt P, Hasan-Ali H, Marandi T, Lehto S, Mansourati J, Kurashvili R, Siasos G, Lengyel C, Thrainsdottir IS, Aronson D, di Lenarda A, Raissova A, Ibrahimi P, Abilova S, Trusinskis K, Saade G, Benlamin H, Petrulioniene Z, Banu C, Magri CJ, David L, Boskovic A, Alami M, Liem AH, Bosevski M, Svingen GFT, Janion M, Gavina C, Vinereanu D, Nedogoda S, Mancini T, Ilic MD, Fabryova L, Fras Z, JiménezNavarro MF, Norhammar A, Lehmann R, Mourali MS, Ural D, Nesukay E, Chowdhury TA (2019) ESC Guidelines on diabetes, pre-diabetes, and cardiovascular diseases developed in collaboration with the EASD. Eur Heart J ;41(2):255-323. doi:https://doi.org/ 10.1093/eurheartj/ehz486

Publisher's note Springer Nature remains neutral with regard to jurisdictional claims in published maps and institutional affiliations. 